\title{
Myxoid Liposarcoma
}

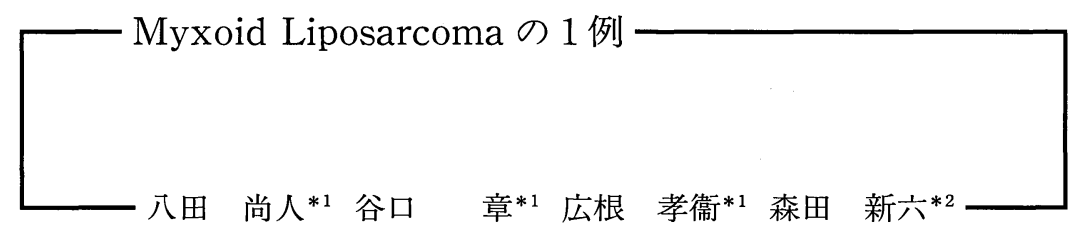

Summary

A 53-year-old female patient with myxoid liposarcoma on the left foot is reported. The patient underwent local excisions before visiting to our hospital. The tumor had been diagnosed as benign. Physical examination revealed a $25 \times 40 \mathrm{~mm}$ soft cutaneous tumor which was located on the forth toe and the adjacent region of the dorsum of left foot. Light microscopy of excised lesion revealed that there were many tumor masses consisting of spindle or oval shaped cells with pleomorphic nuclei and cytoplasm containing numerous small vacuoles in the dermis and subctaneous tissue, and that tumor masses were embedded in an abundant mucoid matrix stained with Alcian blue. It was also shown that tumor masses were not completely removed at the margin of the specimens. The patient received postoperative irradiation with fast neutrons at dose of $17.1 \mathrm{~Gy}$. When last seen, 49 months post-operatively, the patient had no evidence or recurrence or metastasis.

\section{緒言}

脂肪肉腫 (liposarcoma) は軟部組織の悪性腫 瘍の中でも最も頻度の高いものであり，下肢お よび後腹膜に好発する12)。本症の患者は単純摘 出または切除後局所再発を繰返すことが多い が，その予後は横紋筋肉腫，平滑筋肉腫，血管 肉腫などに比べてやや良いとされている1。 我々は切除標本の組織学的所見から腫瘍細胞の 残存が推測された脂肪肉腫例に速中性子線の手 術後照射を行い，良好な結果を得たので報告す る。

${ }^{* 1}$ Naohito HATTA, Akira TANIGUCHI, Takae HIRONE：金沢大学皮膚科学教室

${ }^{* 2}$ Shinroku MORITA : 放射線医学総合研究所病院 部
症例

患 者：53歳，女性

初 診：1987年 7 月23日

主 訴：左足第 4 趾の腫瘤。

家族歴：父は肝硬変，母は胃癌で死亡。

現病歴：1984年頃左足第 4 趾背に腫瘤が生じ た。1986年 3 月, 某医により腫瘤の切除を受け, 粘液囊腫といわれた。間もなく再発したため, 1986年 6 月に再切除を受けた。しかし，その 8 カ 月後に再発し，1987年 7 月当科を受診した。

現 症：左足第 4 趾の背面から足背にかけて $40 \times 25 \mathrm{~mm}$ の比較的軟らかい腫瘤が触知され， その一部に $25 \times 10 \mathrm{~mm}$ の不規則に隆起した硬 い紅色結節が存在した（図 1)。

臨床検査成績：尿，血液像，肝機能，腎機能， 


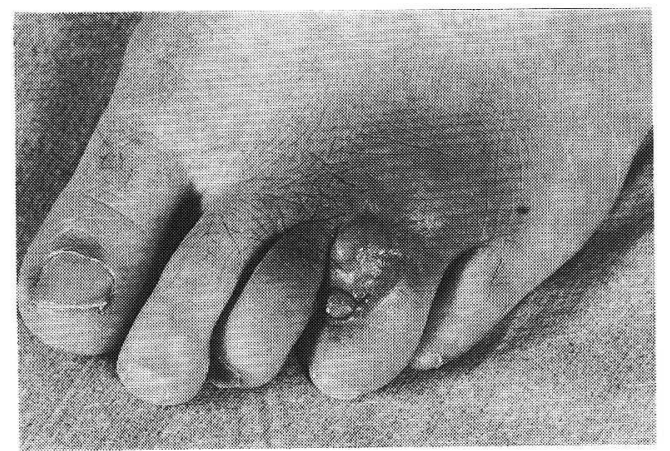

図 1. 初診時の臨床像

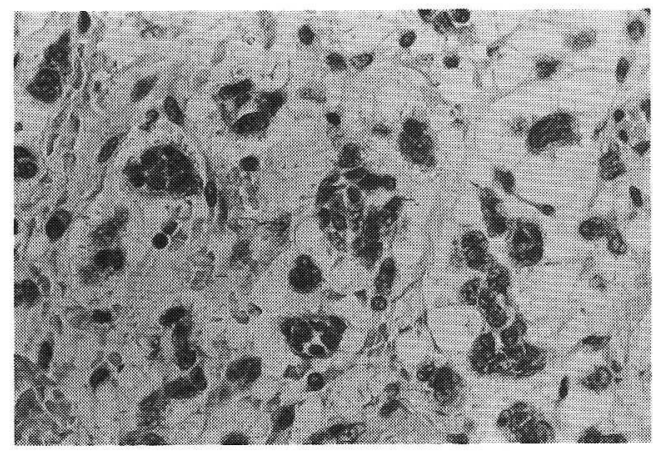

図 3.組織像 (H.E.染色)

腫瘍細胞の細胞質内に空胞があり，数個の多核 細胞もみられる

血清電解質等に異常は認められず，胸部 X 線像 にも異常所見は認められなかった。

組織学的所見：後述の単純切除により得られ た腫瘍の組織像は次のようであった。すなわち， 真皮中層から皮下組織内に種々の大きさの腫瘍 塊が存在し，一部は筋膜に達していた。腫瘍細 胞は紡錘形ないし卵円形で，核は卵円形でクロ マチンに富み，多形性を示した(図 2 )。病巣の 一部では多核細胞も混在していた(図 3 )。腫瘍 細胞の細胞質は明るく，種々の大きさの空胞を 持っていた。空胞内に少量のズダンIII陽性脂質 顆粒を含有する細胞も少数みられた（図 4 )。間 質は粘液様変性を示し，アルシャン青陽性物質 がみられた(図 5 )。以上の組織学的所見により 粘液型 (myxoid type) の脂肪肉腫と診断した。

また，切除標本の両端では腫瘍細胞塊が中断

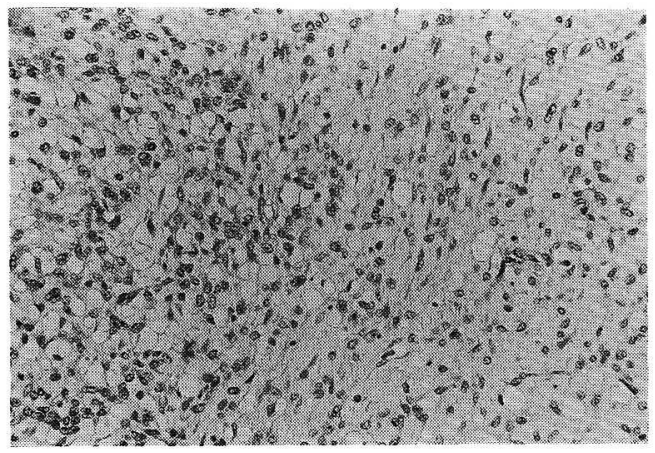

図 2.組織像 (H.E.染色)

紡鏵形ないし卵円形の腫瘍細胞がみられる

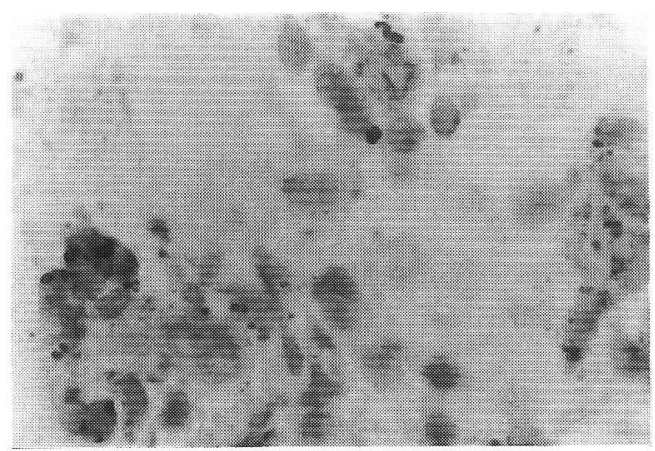

図 4、組織像（ズダンIII染色）

腫湯細胞の細胞質内に少量のズダン III陽性脂質 顆粒がみられる

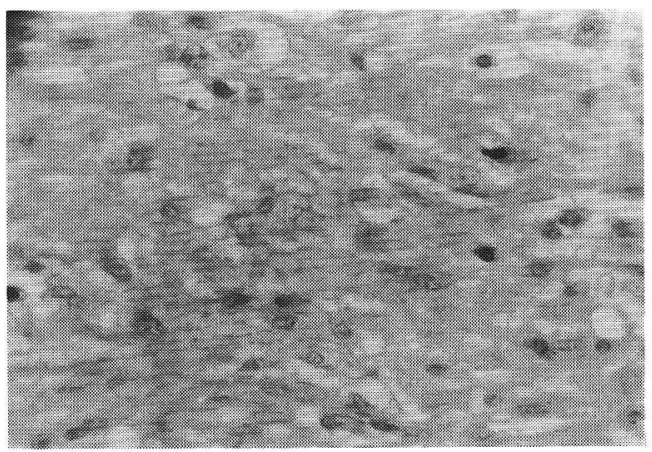

図 5.組織像（アルシャン青染色）

間質は粘液様変性を示し，アルシャン青陽性で ある

されて露出した部位がみられた。このことから 切除は不完全であり，腫瘍細胞は残存している と考えられた。

治療および経過：1987年 9 月17日に腫瘤を単 
純切除した。切除標本の組織学的所見より脂肪 肉腫と診断後全身検索を行ったが，遠隔転移を 示唆する所見は認められなかった。切除標本の 組織像から腫瘍の残存が強く示唆されたので広 範囲切除を勧めたが，患者の同意を得られな かった。そこで速中性子線照射を勧めた。1988 年 2 月より放射線医学総合研究所において左足 全体に速中性子線 $9.9 \mathrm{~Gy}(1.1 \mathrm{~Gy} \times 9)$ を照射 し, さらに第 4 趾を中心に $7.2 \mathrm{~Gy}(1.2 \mathrm{~Gy} \times 6)$ を追加照射した（time-dose fractionation： 108)。照射後 3 年 8 力月, 切除後 4 年 1 力月経 過した時点で再発または転移の徵候は認められ なかった。

\section{考察}

脂肪肉腫の腫瘍細胞は組織学的にいろいろの 形態を示し，比較的分化した型の細胞から全く 未熟な型の細胞まであるので，数種の組織型に 分類されている。田中ら ${ }^{2)}$ は, WHO 分類 ${ }^{3}$ に 従って経験例136例を分類し，分化型（welldifferentiated type）18\%，粘液型（myxoid type) $43 \%$, 円形細胞型 (round-cell type) $3 \%$, 多形型 (pleomorphic type) 29\%, 混合型 (mixed type） $7 \%$ であり，主要な型は粘液型と多形型 であったと述べている。Hajdu王は分化型，粘液 型，線維芽細胞型（fibroblastic type），脂肪芽 細胞型 (lipoblastic type)，多形型の 5 型に分類 しているが，彼のシリーズ (239例) でも高頻度 の型は粘液型（36\%）と多形型（33\%）であっ たと述べている。

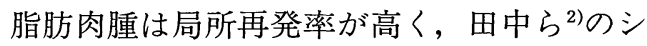
リーズでは初回手術後 5 年経過した時点で再発 率は90\%（36/40）であったと報告されている。 Kindblom ら ${ }^{5}$ は, 再発率は腫瘍の部位により異 なり，部位が後腹膜，下肢，上肢，体幹の場合 に再発率はそれぞれ $82 \% ， 63 \% ， 30 \% ， 50 \%$ で あったが，しかし，再発率はむしろ切除範囲に 左右されるものであり，分化型と粘液型の腫瘍 のうち明らかに根治的に切除されたものの再発
率は35\%（7/20）であったのに対して，根治的 切除を目的として手術したけれども組織学的に 根治的に切除されていなかったものの再発率は 71\% (15/21) であったと述べている。このこと は，腫瘍の部位によって切除範囲が多少とも制 約される場合に再発率が高くなることを示して いる。

再発の頻度に関係する因子として腫瘍の組織 型も指摘されている。Chang ら ${ }^{6}$ は四肢に生じ た脂肪肉腫82例を組織型によって低悪性度群 (分化型, 粘液型) と高悪性度群(脂肪芽細胞型, 線維芽細胞型，多形型）に分けて解析し， 5 年 間局所再発のみられなかった症例数は低悪性度 群ではその $90 \%$ であったが高悪性度群では $60 \%$ と比較的少なく，再発例における再発までの平 均期間は前者で35力月であるのに対して後者で は13力月と比較的短く, 高悪性度群の脂肪肉腫 は再発のリスクが高いと述べている。さらに， 彼らは転移および生存率と組織型の関係につい ても検討し， 5 年間転移のみられなかった症例 数は低悪性度群では $50 \%$ と比較的少なかった が，転移までの平均期間は前者で 27 月，後者 で23カ月とほとんど差異が認められなかったと 述べている。また，分化型，粘液型，線維芽細 胞型，多形型，脂肪芽細胞型脂肪肉腫の 5 年生 存率はそれぞれ $100 \% ， 88 \% ， 58 \% ， 56 \% ， 40 \%$ で，後 3 者の死亡率が高いと報告している。再 発率については, Evans ${ }^{7}$ もまた粘液型脂肪肉腫 は他型のものに比べて再発率が低いと報告して いる。Spittle ら ${ }^{8)}$ およ゙ Reitan ら ${ }^{9} の$ 各シリー ズでも粘液型は他型よりも予後は比較的良好で あると報告されている。

四肢の軟部組織の肉腫の場合，広範囲切除を 行うためには症例の約 $50 \%$ において患肢の切断 術が必要となり ${ }^{10)}$ ，機能面で患者の負担が大き いので，最近では手術前または手術後に $\gamma$ 線な ぞによる放射線治療を併用して切除範囲を縮小 し，機能の温存を図る場合が多くなってい $3^{11112)}$ 。脂肪肉腫は比較的放射線感受性があ り ${ }^{13)}$ ，特に粘液型の場合には放射線治療が有効 
といわれている ${ }^{14)}$ 。自験例の治療に用いられた 速中性子線は，酸素効果が低いので放射線抵抗 性の原因とされる低酸素細胞に対して有効であ $\eta ，$ 細胞の種類や細胞周期の状態による放射線

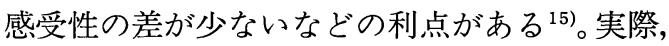
Tsunemoto ら ${ }^{16)}$ は, 軟部組織肉腫の速中性子線 治療例の 5 年生存率は手術前照射の場合 $77.1 \%$ ，手術後照射の場合 $69.8 \%$ であるが，速 中性子線照射のみの場合は $20 \%$ であり，速中性 子線治療は手術時のマージンの縮小に役立つと 述べている。

自験例では切除標本の組織学的所見から腫瘍 の残存が強く示唆されたので速中性子線照射を 行ったわけである。従来の報告では粘液型脂肪 肉腫の場合単純切除から再発までの期間は平均 3 年といわれているので6)7)，切除後 4 年 1 力月 を経過し再発がみられない自験例の場合は，最 終的に結論し得ないけれども，速中性子線の術 後照射は有効であったと思われる。

\section{文献}

1 ) 古屋光太郎, 網野勝久: 悪性軟部腫瘍の分類とそ の治療成績. 癌と化学療法, 6:513-522, 1979.

2 ) 田中雅祐, 檜沢一夫, 藤内守 : 脂肪肉腫 136 例の臨 床病理学的研究. 癌の臨床, $20: 1036-1047,1974$.

3 ) Enzinger, F. M., Lattes, R., Torloni, H. : Histological typing of soft tissue tumours. No. 3., World Health Organization, Geneva, 1969.

4) Hajdu, S. I. : Pathology of soft tissue tumors. Lea \& Febiger, Philadelphia, p250, 1979.

5 ) Kindblom, L. G., Angervall, L., Svendsen, P. : Liposarcoma, A clinicopathologic, radiographic and prognostic study. Acta. Pathol. Micro- biol. Scand. (A) (Suppl. 253) : 1-71, 1975.

6 ) Chang, H. R., Hajdu, S. I., Collin, C., et al. : The prognostic value of hitologic subtypes in primary extremity liposarcoma. Cancer, 64 : 15141520, 1989.

7 ) Evans, H. L. : Liposarcoma, A study of 55 cases with a reassessment of its classification. Am. J. Surg. Pathol., 3 : 507-523, 1979.

8 ) Spittle, M. F., Newton, K. A., Mackenzie, D. H. : Liposarcoma, A review of 60 cases. Br. J. Cancer, $24:$ 696-704, 1970.

9 ) Reitan, J. B., Kaalhus, O., Brennhovd, I. O., et al. : Prognostic factors in liposarcoma. Cancer, 55 : 2482-2490, 1985.

10) Simon, M. A., Enneking, W. F. : The management of soft-tissue sarcomas of the extremities. J. Bone Joint Surg., 58-A : 317-327, 1976.

11) Lindberg, R. D., Martin, R. G., Romsdahl, M. M., et al. : Conservative surgery and postoperative radiotherapy in 300 adults with soft-tissue sarcoma. Cancer, 47 : 2391-2397, 1981.

12) Barkley, H. T., Martin, R. G., Romsdahl, M. M., et al.: Treatment of soft tissue sarcomas by preoperative irradiation and conservative surgical resection. Int. J. Radiat. Oncol. Biol. Phys., 14 : 693-699, 1988.

13) Perry, H., Chu, F. C. H. : Radiation therapy in the palliative management of soft tissue sarcomas. Cancer, 15 : 179-183, 1962.

14) Enterline, H. T., Culberson, J. D., Rochlin, D. B., et al. : Liposarcoma, A clinical and pathological study of 53 cases. Cancer, $13: 932-950$, 1959.

15）森田新六：速中性子線治療. 医学のあゆみ, 150 ： 1036-1039, 1989.

16) Tsunemoto, H., Morita, S., Satoh, S., et al. : Present status of fast neutron therapy in Asian countries. Strahlenther. Onkol., 165 : 330-336, 1989. 